\title{
Correspondence between environmental gradients and the community structure of marsh-edge fishes in a Louisiana estuary
}

\author{
C. F. Rakocinski ${ }^{1, *}$, D. M. Baltz ${ }^{1,2}$, J. W. Fleeger ${ }^{3}$ \\ ${ }^{1}$ Coastal Fisheries Institute, ${ }^{2}$ Department of Oceanography and Coastal Sciences, and ${ }^{3}$ Department of Zoology and Physiology, \\ Louisiana State University, Baton Rouge, Lousiana 70803-7503, USA
}

\begin{abstract}
Patterns in the community structure of marsh-edge fishes occupying the ecotone between marsh surface and open water were revealed through intensive surveys with a drop sampler along two $25 \mathrm{~km}$ transects in a Louisiana estuary during spring and summer 1989. We quantified abundances of organisms and measured environmental variables to characterize community structure and population responses, along large-scale as well as local environmental gradients. Reciprocal averaging ordination of species-by-sample matrices and subsequent visual pattern recognition of superimposed environmental information were used to identify large-scale temporal and spatial changes in community structure. We also recognized responses to gradients in selected local environmental variables, like water depth and emergent stem density. Although responses to local gradients were subordinate to large-scale changes in community structure, local responses were still important in segregating species that co-occurred along large-scale gradients. A close correspondence existed between large-scale spatial and temporal changes in community structure and several abiotic variables, such as salinity, water temperature, and dissolved oxygen. Temporal changes in community structure were more important in spring than in summer. A species turnover during spring involved the virtual replacement of young-of-year of one dominant water-column species, gulf menhaden Brevoortia patronus, by another water-column species, bay anchovy Anchoa mitchilli. A coenocline comprised of several demersal fishes appeared along the transects in summer, and this spatial change in community structure closely followed the salinity gradient. This study extends the applicability of the gradient model of community structure to Gulf of Mexico coastal salt marshes and underscores the importance of nested environmental gradients to ecological segregation.
\end{abstract}

\section{INTRODUCTION}

As transitional zones between marine and freshwater ecosystems, as well as between terrestrial and aquatic ecosystems, estuaries comprise both largescale $(\mathrm{km})$ and local $(\mathrm{m})$ gradients in environmental conditions. Similarly, fish and invertebrate assemblages of estuarine salt marshes fluctuate both temporally and spatially, at least in part, because estuaries also serve as nurseries (Rogers et al. 1984). Phenologies and distributions of estuarine species may follow large-scale temporal and spatial changes in

\footnotetext{
- Present address: Gulf Coast Research Laboratory, 703 East Beach Drive, PO Box 7000, Ocean Springs, Mississippi 39564-7000, USA
}

the environment. Consequently, estuarine community structure may be determined primarily by individualistic population responses to environmental gradients (Boesch 1977. Weinstein et al. 1980). In a hierarchical fashion, species' distributions at particular locations along a large-scale gradient should be influenced by population responses to environmental gradients in local conditions, including short-term tidal fluctuations (Kneib 1984)

The relative importance of environmental gradients to community structure has yet to be fully evaluated for all types of estuaries. Although environmental gradients clearly influence the distribution patterns of estuarine species on the east coast, USA, the importance of gradients to estuarine species of the Gulf of Mexico coast, USA, is not as well studied (Moyle \& 
Cech 1988, Peterson \& Ross 1991). Livingston (1976) attributed the predictable but seasonally dynamic estuarine community structure in Florida to periodic environmental fluctuations and environmental gradients. More recently, Peterson \& Ross (1991) found concurrent changes in fish assemblages and environmental variables along a $17 \mathrm{~km}$ coastal river-estuarine gradient, ranging from tidal freshwater to mesohaline conditions. Thompson \& Forman (1987), however, questioned the relevance of the east-coast gradient model for fish communities in Louisiana's shallow, microtidal estuaries, particularly because species' abundances are seasonally dynamic. Even in estuaries on the east coast of the USA, possible alternative processes, such as physical transport (e.g. prevailing currents) and biotic interactions (e.g. competition and predation) can influence estuarine community structure (Ross \& Epperly 1985). But these processes do not necessarily oppose the effects of environmental gradients on community structure.

Largely because of sampling gear constraints, most previous studies of estuarine communities have not effectively targeted the numerous early life-history stages in ecotonal marsh-edge habitats (Quinn 1980, Thorman 1982, Weinstein \& Brooks 1983, Moyle et al. 1986). Here, we employed a drop sampler similar in design to Zimmerman \& Minello's (1984) to sample all life-history stages occurring within the marsh-edge ecotone. This ecotone can be defined as a transitional zone that ranges from shallow open water in subtidal habitats through periodically flooded emergent vegetation to high intertidal salt marsh habitats, but excluding the marsh interior. We refer to those fishes occupying the marsh-edge ecotone as marsh-edge fishes. Our study design included nested levels of spatial and temporal sampling, thereby allowing a simultaneous appraisal of both large-scale and local gradients as correlates of estuarine community structure.

If environmental gradients are biologically meaningful, a model of community structure that accounts for species turnover should help us to understand the dynamics of estuarine communities. According to the Gaussian model of community structure, independently placed bell-shaped responses by populations to complex environmental gradients result in a gradual species turnover known as a coenocline (Whittaker 1967, Gauch 1982). On the east coast, USA, distributions of estuarine macroinvertebrates and fishes have been shown to directly follow primary salinity gradients in the form of well-defined coenoclines (Boesch 1977, Weinstein et al. 1980). A multivariate extension of the Gaussian model, reciprocal averaging (RA), is appropriate for examining correspondences among multiple environmental gradients and changes in community structure when species turnover is not conspicuous (Wartenberg et al. 1987, Raffaelli et al. 1991). Here, we use RA to identify patterns in the community structure of marsh-edge fishes within the salt marsh zone of a Louisiana estuary. We address the following questions: (1) Do well-defined patterns of change in community structure exist? (2) Do community patterns correspond with large-scale and/or local environmental gradients? (3) Does the relative importance of various environmental gradients to community structure change seasonally, between spring and summer?

\section{STUDY AREA}

The Barataria Basin of Louisiana lies immediately west of the Mississippi River, between the levees of the Mississippi River and Bayou Lafourche. It stretches from the Gulf of Mexico inland for $110 \mathrm{~km}$ (Fig. 1). We sampled in the lower part of the basin, within Barataria and Caminada bays. These bays are separated from the Gulf by a series of barrier islands including Grand Isle and Grand Terre. Our study area was within the productive saltmarsh zone of the basin, which covers 145000 ha (Conner \& Day 1987).

Although shoreline areas are extensive in the Barataria Basin, erosion of salt marsh lands is currently a major concern (Baumann 1987). Historically, the basin was fed by the Mississippi River; however, there has been little direct river flow into the basin for more than 50 yr. Now, the main source of freshwater input to the estuary is from precipitation, averaging $160 \mathrm{~cm} \mathrm{yr}^{-1}$. Salinities in the salt marsh zone vary both seasonally and spatially, usually ranging between 6 and $28 \mathrm{ppt}$. The water is turbid and shallow, typically less than $2 \mathrm{~m}$ deep. Tides are generally diurnal and low, averaging $0.3 \mathrm{~m}$ in amplitude. The climate is subtropical, and the hydrography and salinity are primarily influenced by precipitation, tidal flux, and prevailing winds. Hydrographic conditions are usually relatively stable during summer when weather patterns are less variable (Baumann 1987).

Extensive tidal flats and grassy marshes occur along protected shores of the study area. Substrates are mostly muddy and rich with organic detritus, but sand and clay appear in lower reaches of the study area. Prevalent species of marsh vegetation include Spartina alterniflora (saltmarsh cord grass), Juncus roemerianus (black rush), Distichlis spicata (saltgrass), Batis maritima (saltwort), and Salicornia virginica (glasswort). In the upper reaches of the salt marsh, Spartina alterniflora grades into the brackishwater species, Spartina patens (salt meadow cord grass). 


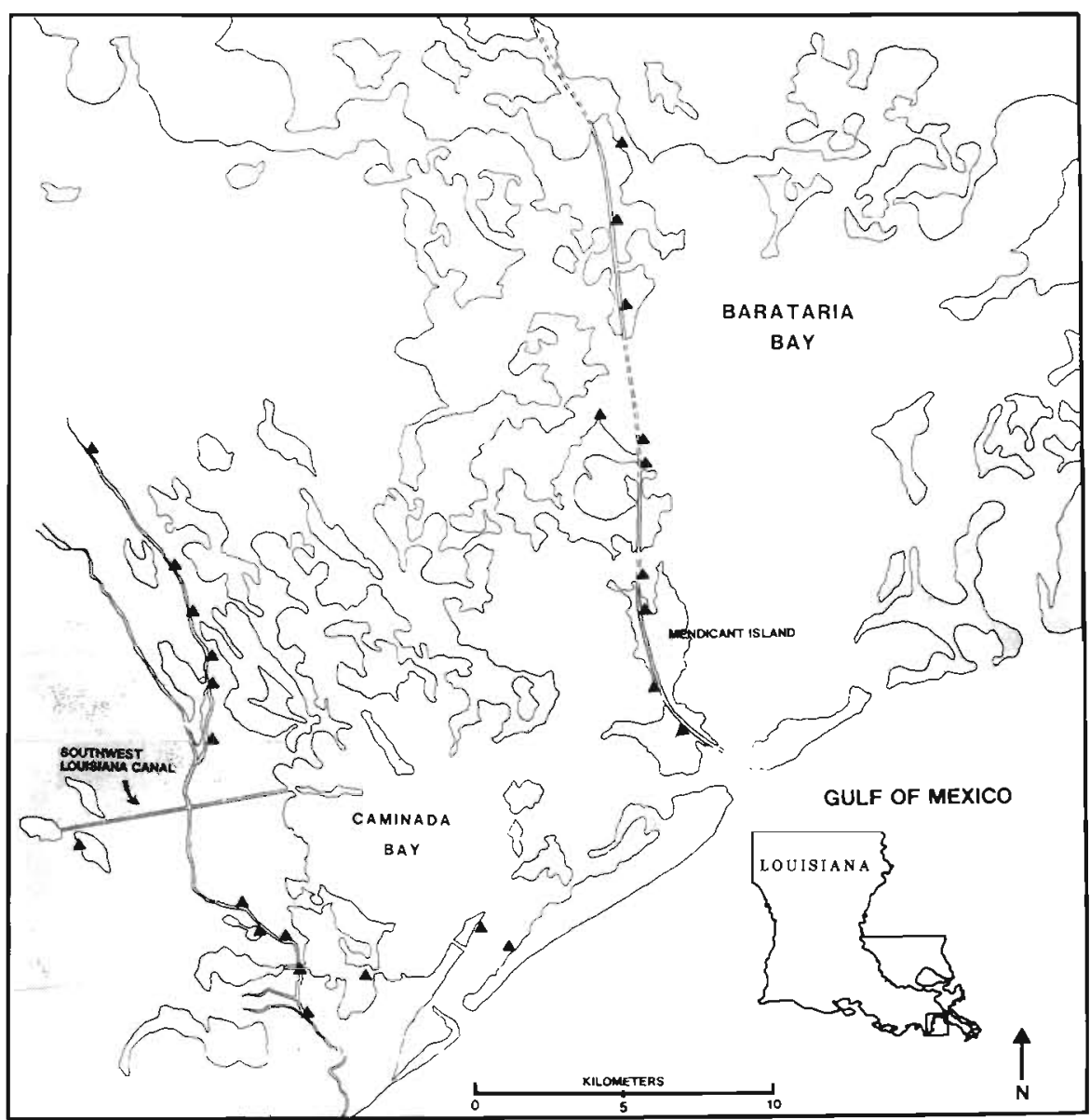

Fig. 1. Study area, showing sampling locations on eastern and western transects. The eastern transect intersects relatively open marsh areas, while the western transect intersects closed marsh areas. The Southwest Louisiana Canal on the western transect and the northern tip of Mendicant Island on the eastern transect were regarded as the dividing line between upper and lower portions of the salt marsh for interpretations of RA ordinations

\section{METHODS}

Sampling. We collected marsh-edge fishes along the shallow shoreline of bayous, tidal creeks, inlets, bays, and islands, using a drop sampler (Zimmerman \& Minello 1984). Our drop sampler was a fiberglass cylinder with an aluminum skirt fixed at the bottom. With it, we could sample an entire water column of $1.19 \mathrm{~m}^{2}$ in area and up to $1 \mathrm{~m}$ in depth. The drop sampler was suspended about $3 \mathrm{~m}$ away from the bow of a small boat and about $0.5 \mathrm{~m}$ above the surface of the water. This sampling technique had several advantages. All sizes of fishes (and most macroinvertebrates) were retained, including postlarval and juvenile stages. Nearly complete sampling of individuals within the enclosed area provided accurate density estimates for most nonburrowing species (Zimmerman \& Minello 1984). Finally, because the area sampled was small and homogeneous, microhabitat level information could be obtained for each sample.
The drop sampler enabled us to effectively sample the biotically important marsh-edge ecotone, a transition zone between the interior marsh-surface and the adjacent open water, where small fishes and macroinvertebrates are abundant. Gear avoidance by the small species and early life-history stages of concern was not apparent in the turbid waters we sampled, although some larger fishes, such as adult striped mullet Mugil cephalus with good aerial vision, occasionally may avoid capture (pers. obs.).

To fully characterize marsh-edge fish communities throughout the salt marsh, we quantitatively sampled marsh-edge habitats, ranging from open water to flooded vegetation, along 2 transects, each running inland from the Gulf coast for roughly $25 \mathrm{~km}$ (Fig. 1). A western transect was located just west of Caminada Bay, and fell within a relatively closed salt marsh characterized as land dissected by water. Another eastern transect, located in the more open waters of Barataria Bay, was characterized as water dissected by 
land. Intensive collecting during spring and summer 1989 yielded a total of 287 drop samples obtained during 11 separate field trips made over $28 \mathrm{~d}$. Our intention was to include the entire range of environmental conditions experienced by diurnal organisms in marsh-edge habitats.

To characterize population responses to concurrent environmental gradients on different spatial scales, we hierarchically stratified our sampling on 4 spatial levels: transect, reach, location, and site (i.e. individual samples). Whenever carrying out a sampling plan of this scope, unexpected problems preclude a perfectly balanced experimental design. For example, our efforts to sample the western transect often were hampered by unfavorable weather, leading to greater emphasis on the eastern transect $164 \%$ of 287 samples). Nevertheless, we distributed our efforts as evenly as possible across the hierarchical strata, and accordingly used a robust analysis to discern important patterns in the data. Between the ends of the upper and lower reaches on both transects, we sampled at 27 locations. During each field trip, we sampled at widely spaced locations in the upper, middle, and lower reaches of a transect. Within locations, sites were stratified to cover the broad range of habitat conditions, including depth and distance from shore. Sites were independent, because samples were always uniquely placed (i.e. individual samples). A mean of 6.7 (range 2 to 12 ) sites were sampled at each location on a given date. The number of sites per location was varied because of gear or weather problems or in order to fully characterize a given location. Typically, within a location, samples were placed at varying distances from the marsh edge or among emergent stems (e.g. Spartina), less than $2 \mathrm{~m}$ into the flooded marsh. Whenever possible, we sampled among emergent vegetation at each location. In all, 75 of the 287 total samples $(26 \%)$ included emergent vegetation. Of the remaining samples, $96(34 \%)$ were in open water $1 \mathrm{~m}$ or less from the marsh edge, and $116(40 \%)$ were in open water greater than $1 \mathrm{~m}$ from the marsh edge.

Environmental variables were measured for each drop sample, including minimum and maximum depths in centimeters and the minimum distance to the marsh edge in meters. Other environmental variables measured for each sample included salinity (ppt), water temperature $\left({ }^{\circ} \mathrm{C}\right.$ ), dissolved oxygen (DO, $\mathrm{mg}^{-1}$ ), current velocity $\left(\mathrm{cm} \mathrm{s}^{-1}\right)$, and turbidity (NTU, Nephelometer Turbidity Units). We used YSI model 33 S-C-T and model 57 oxygen meters, an AO temperaturecompensated refractometer, a Montedoro-Whitney PVM-2 current meter, and a Monitek model 21 PE portable nephelometer. When vegetation was present inside the drop sampler, we identified the species and enumerated emergent stems. Finally, we categorized dominant and subdominant substrates and recorded the dominant marsh vegetation adjacent to each sample.

About $100 \mathrm{~cm}^{3}$ of powdered rotenone suspended in water was applied inside the drop sampler. Affected organisms were removed with dip nets and preserved in $95 \%$ ethanol. After thorough dip-netting, retained water was pumped through a $333 \mu \mathrm{m}$ mesh plankton net. We removed remaining organisms from the substrate by hand or with dip nets. Plankton net contents were fixed in $10 \%$ formalin, and samples were later rinsed with water and transferred to $95 \%$ ethanol. After sorting samples, fishes were identified to species using keys by Lippson \& Moran (1974) and Hoese \& Moore (1977). All fishes were counted and measured to the nearest mm total length (TL).

Data analysis. Reciprocal averaging (RA) is a form of ordination that rearranges a sample-by-species matrix to reflect its inherent order (Hill 1973, Pielou 1984). It is reciprocal in the sense that scores for both species and samples are jointly determined in the same ordination space by their weighted averages. Species scores in RA ordination space mark their centers of abundance and extent of co-occurrence, and relative positions of sample scores reflect their species compositions. Samples with similar RA scores have similar species compositions, whereas species with similar RA scores tend to co-occur. Thus, displays of RA scores for species and samples can be mutually compared to identify their joint associations (Gauch 1982). Distributions of sample RA scores can then be viewed in relation to superimposed environmental information to identify ecological correlates of community structure.

Before performing the RA analysis using BIOITAT (Pimentel \& Smith 1986), we made several decisions about the inclusion of species or life-history stages. Because postlarval naked goby Gobiosoma bosci were periodically abundant as well as morphologically distinct from juveniles and adults, we treated the postlarval stage of this species separately (Livingston 1988). Large gulf menhaden Brevoortia patronus were rare, and only those less than $35 \mathrm{~mm}$ TL were included (i.e. young-of-year). To remove undue effects of rare species on the RA analysis (Gauch 1982), we eliminated species occurring in less than $10 \%$ of the samples. The influence of uncommon species or life-history stages (i.e. $<16 \%$ frequency of occurrence, FO) was reduced by use of a downweighting option. For each drop sample, densities (ind. $\mathrm{m}^{-2}$ ) for every species or life-history stage of concern were entered into the RA ordinations. Because data are rescaled during RA ordination, densities were untransformed (Pielou 1984). Sample scores were initially ordered to range from low to high values to reflect the temporal sequence. After subsequent RA iterations, the resulting sets of scores for 4 RA axes were used to plot both species and samples in RA space. 
To assess whether ecological patterns differed seasonally between spring and summer, we divided our samples into 2 temporal data sets. The spring data set comprised 136 drop samples taken between March and May 1989 and the summer data set comprised 151 drop samples taken between June and August 1989. We then eliminated 4 samples that did not contain any fishes from each season (Pimentel \& Smith 1986). Large-scale temporal changes were assessed within each seasonal data set by assigning samples to either early or latter halves of the temporal sequence. Consequently, spring samples were divided into 2 groups collected either before or after mid-April (i.e. 20 April), and summer samples were divided into 2 groups collected either before or after mid-July (i.e. 19 July).

To appraise large-scale spatial gradients and corresponding changes in community structure, we assigned sampling locations to either upper or lower salt marsh positions, a priori. The SW Louisiana Canal was designated as the dividing line on the western transect, and the northern tip of Mendicant Island divided the eastern transect (Fig. 1). Consequently, 139 of the total 287 drop samples were regarded as upper salt marsh samples for purposes of ecological interpretation.

In conjunction with large-scale spatial and temporal gradients, we considered concurrent abiotic gradients, such as salinity, water temperature, and DO concentration. In addition to large-scale gradients, local environmental variables also were considered, including depth, distance from the marsh edge (i.e. shoreline), emergent stem density, current velocity, turbidity, substrate composition, water temperature, and DO. Hereafter, we consider only those variables that indicated clear ecological patterns.

Following RA ordinations, ecologically important gradients were recognized by first assigning samples to dichotomous groups relative to opposite ends of measured ranges for particular environmental variables. Next, the environmental information was superimposed on RA sample ordinations to identify ecological patterns (Gauch 1982). Gradients were especially apparent for some environmental variables when samples with central values (e.g. water depths 30 to $50 \mathrm{~cm}$ ) were excluded from displays of RA scores. Hence, some displays involved less than the total number of samples. Clear separations or clusters of RA sample scores accordingly indicated important gradients and corresponding changes in community structure.

Some additional statistical tests were useful for interpreting the results of the RA analysis. Nonparametric chi-square tests of association were made for selected demersal and water-column fishes that were implicated by the RA analyses as being either positively or negatively associated with emergent vegetation (Zar 1984). Variance-to-mean ratio tests of dispersion for selected fish species also aided interpretations of the RA analysis.

\section{RESULTS}

Environmental variables (Table 1) and species' abundances (Appendices 1 \& 2) varied considerably among samples and between seasons. Actual depths sampled varied from a minimum of $1 \mathrm{~cm}$ to a maximum of $88 \mathrm{~cm}$. When emergent stems occurred in samples, their numbers varied between 0 and 300 (per $1.19 \mathrm{~m}^{2}$ ) (Table 1). Although typically less than $5 \mathrm{~m}$, distances of sample sites from the marsh edge ranged between 0 and $15 \mathrm{~m}$.

Most fishes caught with the drop sampler were small, less than $35 \mathrm{~mm} \mathrm{TL}$, including postlarvae, juveniles, and small resident adults. Only occasionally were large adult fishes (i.e. $>100 \mathrm{~mm}$ TL), such as sheepshead Archosargus probatocephalus, striped mullet Mugil cephalus, southern flounder Paralichthys lethostigma, and red drum Sciaenops ocellatus, captured. Fifteen common species or life-history stages were included in RA ordinations of spring or summer data sets, including 4 gobies, 3 water-column fishes, 2 postlarval sciaenids, 3 postlarval flatfishes, and 3 other common fishes (Appendices 1 \& 2). Nine common species were included in both seasonal ordinations.

Table 1. Means, standard errors (SE), and ranges for environmental variables measured for 136 spring and 151 summer drop samples

\begin{tabular}{|c|c|c|c|c|c|c|c|c|}
\hline \multirow[t]{2}{*}{ Environmental variable } & \multicolumn{4}{|c|}{ Spring } & \multicolumn{4}{|c|}{ Summer } \\
\hline & Mean & \pm & $\mathrm{SE}$ & (Range) & Mean & \pm & SE & (Range) \\
\hline Salinity (ppt) & 16.2 & \pm & 0.2 & $(9-22)$ & 15.8 & \pm & 0.4 & $(4-28)$ \\
\hline Water temperature $\left({ }^{\circ} \mathrm{C}\right)$ & 25.0 & \pm & 0.3 & $(16-31)$ & 29.9 & \pm & 0.1 & $(26-34)$ \\
\hline Dissolved oxygen $\left(\mathrm{mg} \mathrm{l}^{-1}\right)$ & 7.5 & \pm & 0.1 & $(5-11)$ & 7.1 & \pm & 0.1 & $(4-11)$ \\
\hline Turbidity (NTU) & 21.9 & \pm & 1.3 & $(2-75)$ & 18.2 & \pm & 0.7 & $(4-44)$ \\
\hline Current velocity $\left(\mathrm{cm} \mathrm{s}^{-1}\right)$ & 3.6 & \pm & 0.4 & $(0-32)$ & 3.1 & \pm & 0.2 & $(0-20)$ \\
\hline Mid-depth $(\mathrm{cm})$ & 39.3 & \pm & 1.1 & $(11-79)$ & 41.7 & \pm & 1.1 & $(12-85)$ \\
\hline Number of stems & 9.0 & \pm & 2.6 & $(0-300)$ & 6.4 & \pm & 1.5 & $(0-128)$ \\
\hline Distance from marsh-edge (m) & 1.4 & \pm & 0.2 & $(0.1-15.0)$ & 1.6 & \pm & 0.1 & $(0.1-8.2)$ \\
\hline
\end{tabular}


Three species were only included in the spring ordination: gulf menhaden, skilletfish Gobiesox strumosus, and pinfish Lagodon rhomboides; and 3 fishes were only included in the summer ordination: young-of-year silver perch, young-of-year spotted seatrout, and juvenile lined sole Achirus lineatus.

A total of 5523 individual fishes belonging to 30 species were collected in the 132 spring samples. The 12 species or life stages included in the spring RA ordination comprised $96.9 \%$ of the total number of individuals (Appendix 1). Young-of-year gulf menhaden (i.e. less than $35 \mathrm{~mm}$ TL) made up $51 \%$ of the total number. Two other species, darter goby Gobionellus boleosoma and speckled worm eel Myrophis punctatus, had the highest frequency of occurrence in spring samples ( $\mathrm{FO}=66$ and $61 \%$, respectively).

The 147 summer samples contained 5980 individual fishes belonging to 40 species. The 12 species or life stages included in the summer RA ordination comprised $97.7 \%$ of the total number of individuals (Appendix 2). Postlarval and adult naked goby were both abundant (33 and $26 \%$ of total number) and common (FO $=57$ and $70 \%$, respectively). Bay anchovy also was abundant ( $11 \%$ of total number) and common $(\mathrm{FO}=33 \%)$. Other species appearing frequently in summer included the speckled worm eel $(\mathrm{FO}=69 \%)$ and the darter goby $(\mathrm{FO}=48 \%)$.

\section{Ordination of spring samples}

Eigenvalues of RA axes for the spring ordination decreased gradually, indicating that each of the 4 axes represented considerable variance (Table 2). Two water-column species, gulf menhaden and tidewater silverside Menidia beryllina, were widely separated from each other and from the other 9 species by the first 2 RA axes (Fig. 2A). Both of these water-column species were widespread schooling fishes. Gulf menhaden, however, were concentrated in the lower marsh (Fig. 2A, C). A third common water-column species, bay anchovy, was not separated from the other 9 species on the first 2 RA axes (Fig. 2A). Four other species, including blackcheek tonguefish Symphurus plagiusa, bay whiff Citharichthys spilopterus, darter

Table 2. Eigenvalues of the first 4 axes from RA ordinations of spring and summer data sets. Square roots of eigenvalues estimate correlation coefficients between sets of RA scores for species and samples

\begin{tabular}{ccc|}
\hline Axis & Spring & Summer \\
\hline 1 & 0.93 & 0.69 \\
2 & 0.71 & 0.56 \\
3 & 0.65 & 0.42 \\
4 & 0.42 & 0.41 \\
\hline
\end{tabular}

goby, and pinfish, were close on all 4 RA axes (Figs. 2A \& $3 \mathrm{~A}$ ), reflecting their frequent co-occurrence. RA Axis 3 separated these species from the skilletfish and another cluster of species made up of the 3 watercolumn species, the speckled worm eel, and 3 goby taxa. The skilletfish, a species often occurring with shell substrate, was separated from all other species on RA Axis 4

When the spring data set was divided into early and late sequences, and then superimposed on plots of sample RA scores, a marked temporal change in community structure indicative of a species turnover was apparent (Figs. 2A, B \& 3A, B). The most notable change was the abrupt replacement of young-of-year gulf menhaden by bay anchovy as the predominant water-column species during late spring. The fish assemblage was dominated by 5 species during early spring, including gulf menhaden, bay whiff, darter goby, pinfish, and blackcheek tonguefish (Figs. 2A \& $3 \mathrm{~A})$, but it was dominated during late spring by other taxa, including postlarval naked goby, adult naked goby, clown goby, and bay anchovy.

Temporal changes in community structure also coincided with gradients in abiotic conditions. Dissolved oxygen and water temperature were inversely related variables that changed in concert with community structure during spring (Fig. 3). The pattern of sample RA scores for these variables revealed seasonal variation exceeding diel and local variation (Fig. 3C, D). Fishes experienced lower water temperatures and higher DO levels in early spring than in late spring.

Plots of sample scores also reflected local gradients in some environmental variables, but to a lesser extent than for large-scale environmental gradients. In spring, some species were apparently segregated by depth on RA Axes 1 and 2 (Fig. 2A, D). As shown by a lack of sample scores corresponding with gulf menhaden on the graph of RA Axes 1 and 2, juvenile menhaden were poorly represented in both shallow and deep samples, implying that they were relatively abundant at intermediate depths $(30$ to $50 \mathrm{~cm}$ ). Tidewater silverside were not abundant in deep samples; however, naked goby were sometimes abundant in deep samples, particularly as postlarvae.

Marsh-edge fishes often responded to the density of emergent stems as a local variable. Thirty-eight of 136 spring samples $(28 \%)$ were taken among emergent stems. Patterns of sample scores on RA Axes 1 and 2 indicated that most demersal species associated with emergent stems (Fig. 2A, E). A lack of any stem samples corresponding with gulf menhaden, however, indicated this species avoided emergent stems. Another water-column species, the tidewater silverside, only occurred with emergent vegetation when stem densities were sparse $\left(<14\right.$ emergent stems $\mathrm{m}^{-2}$ ). 


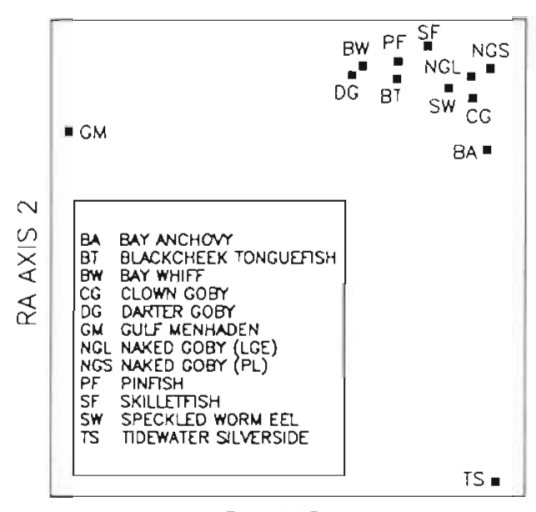

RA AXIS I

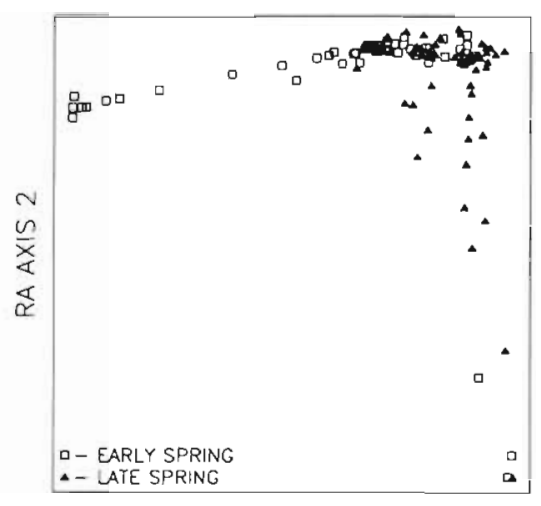

RA AXIS 1

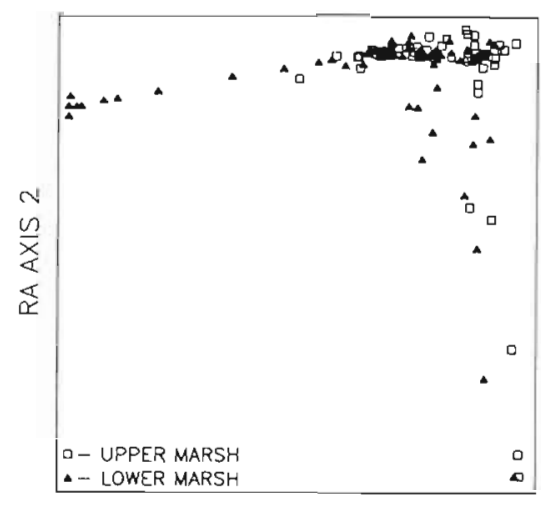

RA AXIS 1 A

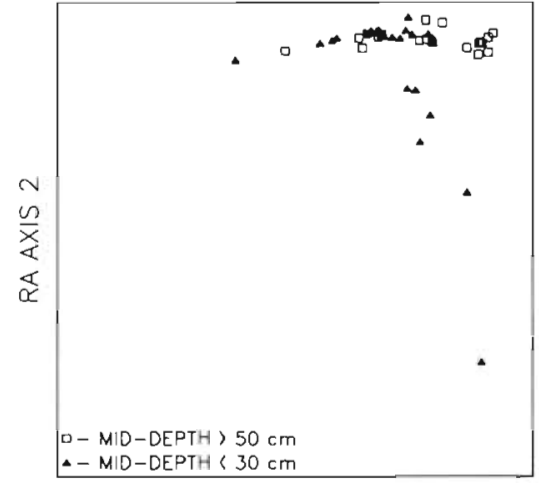

RA AXIS 1

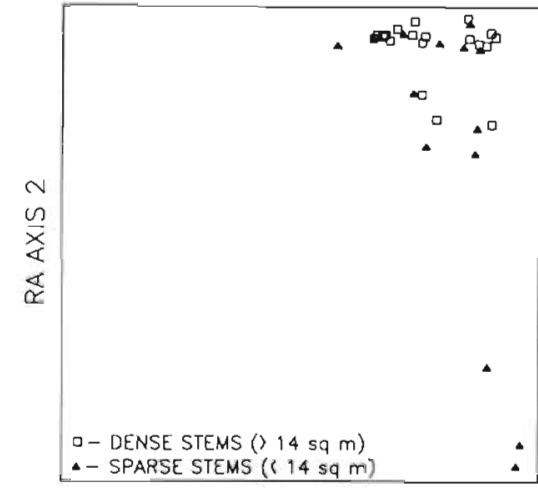

E.

RA AXIS 1

Fig. 2. Plots of scores on the first 2 RA axes for 132 samples of fishes in the spring 1989 data set. (A) displays species' scores, while (B) to (E) display comparable sample scores for the environmental variables. For several variables, sample scores from the middle segments of ranges for environmental variables are not displayed. Consequently, the number of samples displayed may not equal the total number examined. Species codes in (A) are presented in Appendix 1

\section{Ordination of summer samples}

Eigenvalues for the summer data set decreased gradually and were generally lower than the spring eigenvalues (Table 2). Because RA Axes 3 and 4 were uninformative, we concentrated on interpreting RA Axes 1 and 2 for the summer data set. Ordination scores for the summer fishes were widely arrayed in RA space (Fig. 4A). The darter goby, postlarval naked goby, and the tidewater silverside occupied terminal positions in the space formed by RA Axes 1 and 2. Two water-column fishes, bay anchovy and tidewater silverside, stood apart from the other species and from each other on RA Axis 1, indicating they were not closely associated. Three juvenile flatfishes, blackcheek tonguefish, bay whiff, and lined sole, often cooccurred and were clustered in RA space. Clown goby Microgobius gulosus also co-occurred with the flatfishes. Frequent co-occurrence of spotted seatrout and silver perch also was reflected in their similar positions in RA space.
A temporal change in community structure was not apparent within the summer samples (Fig. 4B). Instead, there was a definite large-scale spatial pattern in community structure related to salt marsh position, illustrated by a distinct separation of upper and lower sample scores primarily along RA Axis 2 (Fig. 4C). Except for the 2 water-column species, bay anchovy and tidewater silverside, centers of abundance of the demersal species were clearly arrayed along the spatial gradient in saltmarsh position (Fig. 4A, C). Three flatfishes, the darter goby, and the clown goby, were centered in the lower salt marsh. In contrast, postlarval and adult naked goby concentrated in the upper salt marsh. Distributions of spotted seatrout, silver perch, and speckled worm eel were centered in mid-marsh reaches, as shown by RA scores for these species, which fell within the transition area between sample groups representing the upper and lower halves of the salt marsh.

Salinity was the primary abiotic variable coinciding with the large-scale spatial change in community 


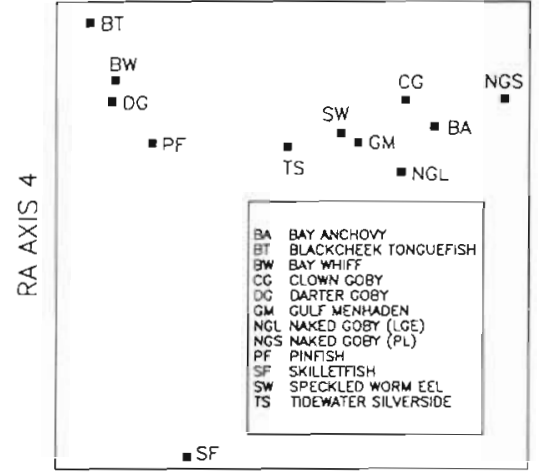

RA AXIS 3

A

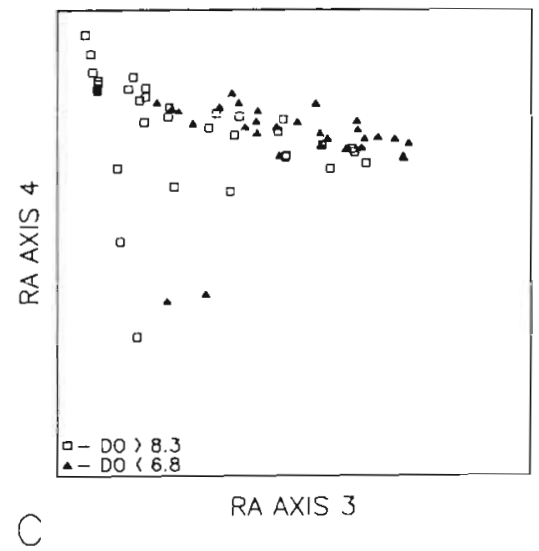

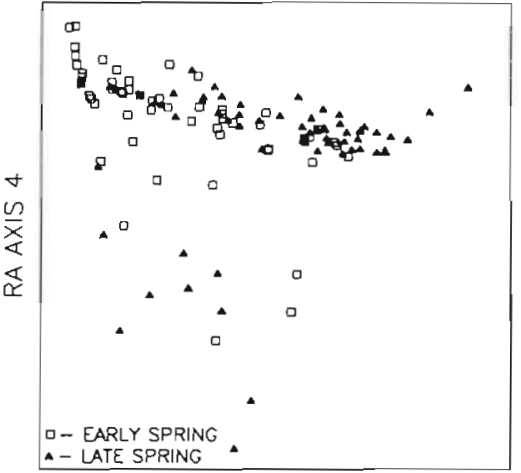

RA AXIS 3

B

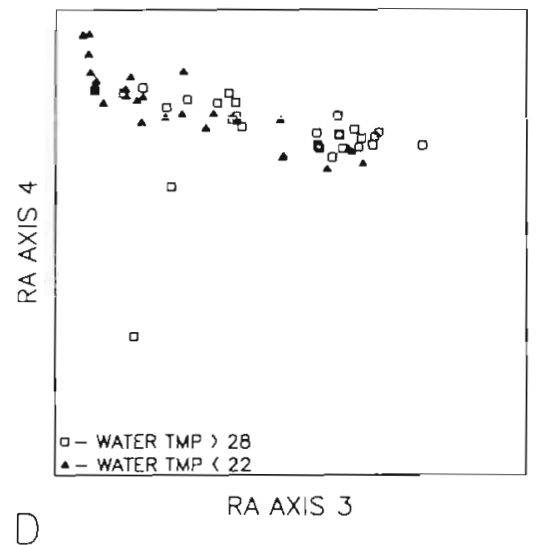

Fig. 3. Plots of scores on RA Axes 3 and 4 for 132 samples of fishes in the spring 1989 data set. (A) displays species' scores, while (B) to (D) display comparable sample scores for the environmental variables. Species codes in (A) are presented in Appendix 1. TMP: temperature $\left({ }^{\circ} \mathrm{C}\right)$; DO: dissolved oxygen $\left(\mathrm{mg} \mathrm{l}^{-1}\right)$ structure. The clear separation of sample groups according to marsh position was matched by an equally clear separation of sample groups based on salinity (Fig. 4C, D). A distinct correspondence occurred between low salinities (<14 ppt) in the upper salt marsh and high salinities (>19 ppt) in the lower salt marsh. Hence, the demersal species also were arrayed along the salinity gradient. Certain species, like the naked goby, experienced relatively low salinities, whereas other species, like the darter goby, experienced relatively high salinities.

In addition to large-scale spatial changes, local patterns in community structure also appeared in the summer data set. Several species segregated along the depth gradient in both upper and lower halves of the estuary (Fig. 4A, E). In the lower half, juvenile flatfishes segregated from the darter goby along the depth gradient, as shown by distinct groups of sample RA scores both characteristic of these species and of deep (flatfishes) or shallow (darter goby) water. In the upper estuary, the center of distribution for postlarval naked goby again was characterized by samples from relatively deep water. Species centered in the mid-estuary, however, including spotted seatrout, silver perch, and speckled worm eel, occurred at various depths, as reflected by sample scores characteristic of these species from both shallow and deep water.

\section{Tests of association with emergent stems}

Although fishes were generally abundant among emergent stems in summer, different fish species varied in their degree of association with emergent stems (Fig. 4A, F), In all, 37 of the 151 summer samples $(24.5 \%)$ contained emergent stems. The darter goby's position in RA space coincided with several samples containing emergent stems in the lower salt marsh. Samples characteristic of spotted seatrout and silver perch also included stems, as shown by the cluster of stem-sample scores corresponding with the RA scores for these species. Several samples characteristic of naked goby also included stems. By contrast, samples characteristic of the flatfishes seldom included stems, and bay anchovy were poorly represented in samples containing stems.

Tests of association confirmed that some species occurred significantly more frequently than expected among emergent stems (e.g. spotted seatrout and silver perch). Whereas just $24 \%$ of 151 summer 

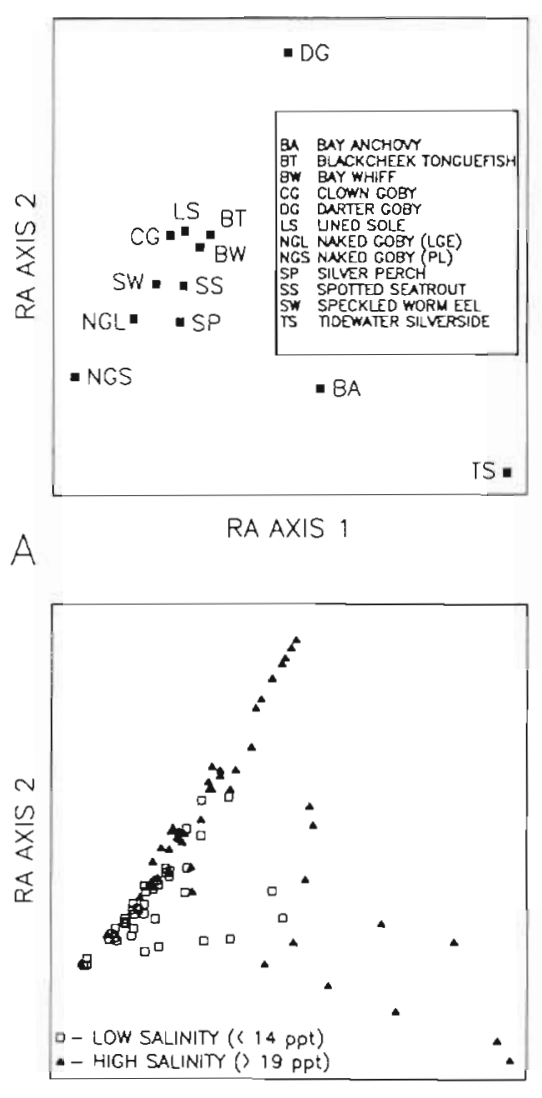

D
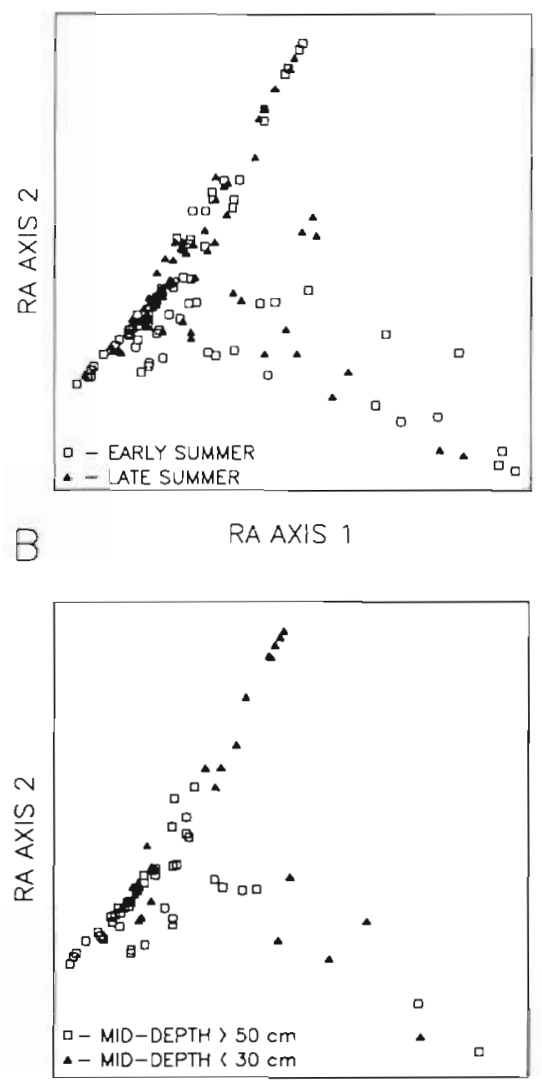

RA AXIS 1

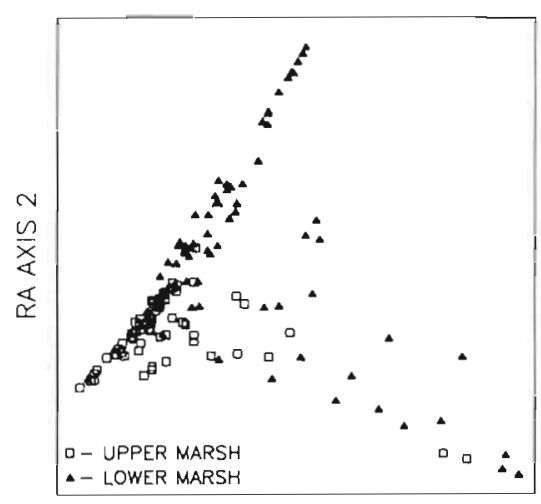

C RA AXIS 1

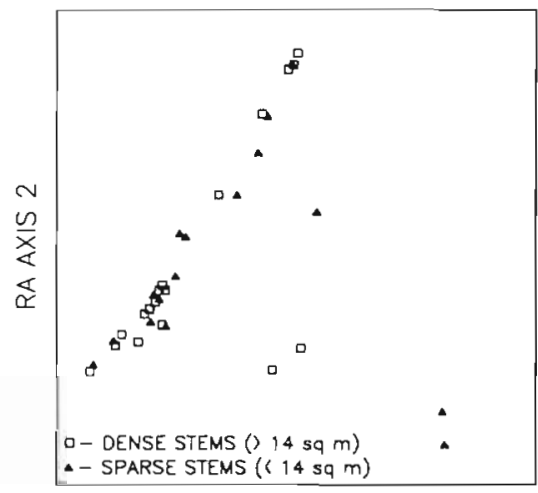

F

RA AXIS 1

Fig. 4. Plots of scores on the first 2 RA axes for 147 samples of fishes in the summer 1989 data set. (A) displays species' scores, while $(B)$ to $(F)$ display comparable sample scores for the environmental variables. Species codes in (A) are presented in Appendix 2

samples included emergent stems, $46 \%$ of 26 samples with spotted seatrout $\left(x^{2}=5.6,1 \mathrm{df}, \mathrm{p}<0.025\right)$ and $62 \%$ of 16 samples with silver perch $\left(\chi^{2}=10.8,1 \mathrm{df}\right.$, $\mathrm{p}<0.05)$ also included emergent stems. Conversely, 2 water-column species (gulf menhaden and bay anchovy) occurred significantly less frequently than expected among emergent stems. Twenty-eight percent of 136 spring samples were taken among emergent stems, but only one of 23 samples containing young-of-year gulf menhaden $\left(x^{2}=5.9,1 \mathrm{df}, p<0.025\right)$ and one of 17 samples containing bay anchovy $\left(x^{2}=\right.$ $3.9,1 \mathrm{df}, \mathrm{p}<0.05$ ) also included emergent stems.

In summary, most of the 15 common species and life stages differed in temporal, large-scale spatial, or local conditions (Table 3). These species fit into 4 temporal groups according to different patterns of recruitment to marsh-edge habitats as postlarvae or juveniles. Three species, gulf menhaden, pinfish, and skilletfish, were common only in spring, with RA scores reflecting their early seasonal recruitment. Five species were common during both spring and summer, with RA scores reflecting their initial recruitment in early spring and prolonged residence in marsh-edge habitats, including bay whiff, blackcheek tonguefish, darter goby, speckled worm eel, and tidewater silverside. Four other taxa were common during both spring and summer, with RA scores reflecting their initial appearance in late spring, including bay anchovy, clown goby, and both postlarval and adult naked goby. Finally, 3 species were common only in summer, reflecting their late recruitment to marsh-edge habitats, including lined sole, silver perch, and spotted seatrout. Members of 3 pairs of similar species or life stages were closely associated in similar habitats, including bay whiff with blackcheek tonguefish, postlarval with adult naked goby, and silver perch with spotted seatrout.

\section{DISCUSSION}

The marsh-edge fish community was distinct, differing substantially from the adjacent open-water community of large fishes (Thompson \& Forman 1987), and 
Table 3. Summary of distributional characteristics for the 15 species and life stages included in RA ordinations of spring and summer data sets. Characteristics were attributed to taxa according to interpretations of sample RA scores as covered in the text. Temp. = temperature $; \mathrm{DO}=$ dissolved oxygen $;$ YOY = young-of-year $; \mathrm{pl}=$ postlarvae $; \mathrm{Mid}=$ mid-marsh Wide $=$ widespread $;$ Int. $=$ intermediate; Shal. = shallow; Neg. = negative; Pos. = positive. See Appendices 1 \& 2 for full species names

\begin{tabular}{|c|c|c|c|c|c|c|c|}
\hline Species (life stage) & Seasonal; temporal & $\begin{array}{l}\text { Spring } \\
\text { temp. }\end{array}$ & $\begin{array}{l}\text { Spring } \\
\text { DO }\end{array}$ & $\begin{array}{l}\text { Marsh } \\
\text { locale }\end{array}$ & $\begin{array}{l}\text { Summer } \\
\text { salinity }\end{array}$ & $\begin{array}{l}\text { Water } \\
\text { depth }\end{array}$ & $\begin{array}{c}\text { Stem } \\
\text { affinity }\end{array}$ \\
\hline Bay anchovy & Spring \& summer; late spring & High & Low & Wide & Wide & Int. & Neg. \\
\hline Blackcheek tonguefish & Spring \& summer; early spring & Low & High & Lower & High & Deep & Neg. \\
\hline Bay whiff & Spring \& summer; early spring & Low & High & Lower & High & Deep & Neg. \\
\hline Clown goby & Spring \& summer; late spring & High & Low & Lower & High & Deep & Int. \\
\hline Darter goby & Spring \& summer; early spring & Low & High & Lower & High & Shal. & Pos. \\
\hline Gulf menhaden (YOY) & Spring $_{i}$ early spring & Low & High & Lower & - & Int. & Neg. \\
\hline Lined sole & Summer; - & - & - & Lower & High & Deep & Neg. \\
\hline Naked goby (large) & Spring \& summer; late spring & High & Low & Upper & Low & Deep & Pos. \\
\hline Naked goby (pl) & Spring \& summer $r_{i}$ late spring & High & Low & Upper & Low & Deep & Int. \\
\hline Pinfish & Spring; early spring & Low & High & - & - & - & - \\
\hline Silver perch & Summer; - & - & - & Mid & Int. & Wide & Pos. \\
\hline Skilletfish & Spring; early spring & Low & High & - & - & - & - \\
\hline Spolied sedroul & Summeri - & - & - & Mid & Int. & Wide & Pos. \\
\hline Speckled worm eel & Spring \& summer; early spring & Low & High & Mid & Int. & Wide & Int. \\
\hline Tidewater silverside & Spring \& summer; early spring & Low & High & Wide & Wide & Wide & Int. \\
\hline
\end{tabular}

from the interior marsh-surface community, composed mainly of resident fundulids (Rozas et al. 1988, Hettler 1989). The nearby sandy-beach surf-zone provides a nursery habitat for yet another fish community (Ross et al. 1987). We believe that these different estuarine fish communities represent species-specific differences in habitat use rather than gear bias.

It is also important to recognize that the gradient model of community structure can be applied to microtidal estuaries in the northwestern Gulf of Mexico, which comprise a large fraction of remaining US coastal wetlands. Other Gulf of Mexico studies of estuarine gradients were focused at the interface between freshwater and estuarine fish assemblages, where marked species turnover occurs (Rounsefell 1964, Felley 1987, Hastings et al. 1987, Peterson \& Ross 1991). By contrast, our study examined distribution patterns on a finer level of resolution, completely within the estuarine fish assemblage. Due to gear limitations of seines and trawls, most previous studies of estuarine fish communities focus on large juveniles and adults in relatively open water. Our drop sampler, however, quantified the abundant small and early lifehistory stages of estuarine fishes that use ecotonal marsh-edge habitats. This detailed approach elucidated local as well as large-scale gradients in species distributions and community structure.
Distinct patterns in the community structure of marsh-edge fishes involving different species associations were clarified by plots of species RA scores. Furthermore, comparable plots of sample scores reflected large-scale temporal and spatial changes in community structure that also coincided with abiotic environmental gradients. In this subtropical microtidal estuary, the relative importance of large-scale environmental gradients changed between seasons, from a temporally dominated to a spatially dominated system. Multiple environmental gradients acted at different times and on different scales in concert with changes in community structure. Moreover, nested within large-scale gradients were local environmental gradients that coincided with other changes in community structure. For example, several fish species varied in relation to water depth and emergent stem density.

Previous estuarine fish studies document both temporal and spatial changes in concert with changes in the physical environment (Keup \& Bayless 1964, Zilberberg 1966, Subrahmanyam \& Drake 1975. Livingston 1976, Weinstein et al. 1980, Ross \& Epperly 1985, Moyle et al. 1986, Felley 1987, Hastings et al. 1987, Peterson \& Ross 1991). Again, we identified separate temporal and spatial changes in estuarine community structure, with temporal changes dominant 
in spring and spatial changes dominant in summer. This seasonal alternation in large-scale gradients may help explain why other studies differ in their estimation of the importance of salinity gradients to the distribution of estuarine species. In this study, the marked shift in dominant fish species during spring also was accompanied by increasing water temperature and decreasing dissolved oxygen concentrations. Thus, in late winter and early spring, when rainy conditions often prevail in estuaries of the southeastern US, attendant low water temperatures and high dissolved oxygen concentrations may permit transient estuarinedependent species to enter low-salinity waters (Rogers et al. 1984, Felley 1987).

Partly because the marsh-edge ecotone provides many elements of the nursery function for various estuarine-dependent species, the estuarine community is dynamic (Subrahmanyam \& Drake 1975, Shenker \& Dean 1979, Blaber \& Blaber 1980, Rogers et al. 1984). For example, the marked species changes during spring could largely be attributed to a temporal succession of recruitment periods for various transient species (cf. Subrahmanyam \& Coultas 1980). When viewed on a long-term annual scale, however, estuarine fish communities appear to change in recurring cycles, implying they are actually stable (Livingston 1976, Weinstein et al. 1980). The most striking temporal change was the replacement of young-of-year gulf menhaden by bay anchovy in the marsh-edge ecotone. This replacement has been noted in other studies and apparently coincides with an abrupt ontogenetic niche shift by zooplanktivorous juvenile gulf menhaden away from the marsh edge to more open waters where they feed on detritus (Deegan \& Thompson 1985). The annual decline of juvenile menhaden in the marsh-edge ecotone might be related to ecological interactions with bay anchovy (Connell 1980), which subsequently occupy marsh-edge habitats for a protracted period lasting more than 5 mo.

Small demersal fishes were ordered along a largescale spatial gradient between upper and lower marsh reaches during summer, when relatively stable hydrological conditions typically create a well-defined salinity gradient in this Louisiana salt marsh (Baumann 1987). Hence, the spatial coenocline corresponded closely with a salinity gradient. Salinity levels may physiologically limit the spatial distributions of some fishes, but estuarine fishes are typically euryhaline (Rogers et al. 1984, Moser \& Gerry 1989). Nevertheless, it is more likely that many estuarine-dependent fishes have characteristic salinity optima. Whether fishes were transients or residents had no bearing on where they were centered along the salinity gradient (cf. Weinstein et al. 1980). Weinstein et al. (1980) concluded that the large-scale salinity gradient was the primary factor influencing the community structure of estuarine fishes and that biotic interactions were secondary. Ross \& Epperly (1985), however, concluded that other large-scale physical processes, such as seasonally variable hydrology and current patterns, directly determined the distributions of estuarine fishes. Regardless of the actual dispersal mechanism, our study supports the idea that salinity is a primary abiotic correlate with estuarine fish community structure.

Three schooling water-column species, gulf menhaden, bay anchovy, and tidewater silverside, usually were separated from each other and from the demersal species in ordination space, indicating they occurred independently. Bay anchovy and tidewater silverside were weakly associated, however, as reflected by adjacent species scores on one or more RA axes in both spring and summer. The water-column species are often regarded as estuarine migrants that can easily enter low-salinity upper-marsh areas (Rogers et al. 1984, Felley 1987, Hastings et al. 1987). In this study, however, young-of-year gulf menhaden were best characterized by lower marsh samples. Although the spatial distributions of most marsh-edge fishes were aggregated to some extent, variance-to-mean ratios showed particularly clumped dispersion patterns for the water-column species ( $\chi^{2}$-tests, $\left.p<0.0001\right)$; and young-of-year menhaden were the most aggregated of all species examined.

In addition to large-scale changes, local patterns in estuarine community structure appeared. Differences existed among species along the local depth gradient ( 0 to $1 \mathrm{~m}$ ) in both upper and lower portions of the salt marsh. For example, in the lower portion during summer, the darter goby concentrated in shallow water and segregated from juveniles of 3 cryptic flatfishes in deeper water. In spring, small gulf menhaden were relatively abundant at intermediate depths (30 to $50 \mathrm{~cm}$ ). While it is difficult to identify the causes for local segregation patterns, habitat selection may integrate many factors such as competition, predation risk, and food availability (cf. Werner et al. 1983), but few experimental studies have addressed interactions of marsh-edge fishes. Undoubtedly, biotic interactions influence whether small fishes utilize marsh-edge habitats and may explain some of the observed microhabitat segregation.

Emergent vegetation, such as cord grass, is a distinctive feature of the marsh-edge environment that is potentially linked to recruitment success for many species. Small marsh-edge fishes may closely associate with emergent vegetation to take refuge from predators and to find food (i.e. a place where prey accumulate) (Van Dolah 1978, Boesch \& Turner 1984, 
Gleason 1986, Gleason \& Wellington 1988). Indeed, young-of-year sciaenids, spotted seatrout, and silver perch occurred more frequently than expected among emergent stems. By contrast, 2 water-column fishes, gulf menhaden and bay anchovy, occurred less frequently than expected among emergent stems.

For fishes that utilize estuaries as nurseries, interactions among biotic and abiotic environmental factors may influence cohort survival, individual growth, and ultimately, recruitment (Sissenwine 1984). Hence, recruitment success is probably linked with microhabitat selection by estuarine-dependent fishes. For example, the availability of flooded cordgrass stems to early life-history stages of some fish and invertebrate species probably directly affects cohort survival and growth. Thus, seasonal and annual variation in the timing and extent of high water conditions (Sasser 1977) may account in part for annual variation in recruitment for some species by mediating access to flooded vegetation. In fact, the duration and frequency of flooding of the salt marsh ecotone vary considerably among years in Louisiana (Childers et al. 1990).

Acknowledgements. We thank several LSU graduate students for their invaluable assistance with field sampling, including Walter Gibson, John McCall, Michael Saucier, and Bin Sun. Jim Ditty kindly identified some unknown larval fishes. Several student workers carefully sorted samples, including Ercelle Anthony, Mike Bigalke, Karen Linton, Beverly Petty, and Will Petty. Karen Linton also drew Fig. 1. Special thanks go to reviewers of preliminary versions of this paper, including Peter B. Moyle, Stephen T Ross, Steve W. Ross, and the LSU CFI fish ecology lunch group. This study was funded by Sea Grant Project Number R/CFB-9 and by MARFIN Project Number NA89WC-H-MF029.

Appendix 1. List of 30 species occurring in 132 spring drop samples, ranked by numerical abundance. Twelve species and lifehistory stages (i.e. those with codes) occurred frequently enough $(>0.10)$ to be included in the spring RA ordination. These 12 species and life-history stages made up $97 \%$ of the 5523 fishes collected in spring. Densities calculated in no. $\mathrm{m}^{-2}$ for all samples in which that taxon occurred (i.e. excluding samples without any individuals). pl $=$ postlarvae; Num. $=10 t a l$ number;

Prop. = proportion; Freq. = frequency of occurrence; $\mathrm{MD}=$ mean density; $\mathrm{SE}=$ standard error of density

\begin{tabular}{|c|c|c|c|c|c|c|c|}
\hline \multirow[t]{2}{*}{ Species } & \multirow[t]{2}{*}{ Code } & \multicolumn{4}{|c|}{ Abundance } & \multicolumn{2}{|c|}{ Occurrence } \\
\hline & & Num. & Prop. & MD & SE & Freq. & Prop. \\
\hline Gulf menhaden Brevoortia patronus & GM & 2836 & 0.51 & 108.3 & 53.1 & 22 & 0.17 \\
\hline Naked goby (pl) Gobiosoma bosci & NGS & 641 & 0.12 & 16.9 & 7.7 & 32 & 0.24 \\
\hline Darter goby Gobionellus boleosoma & $\mathrm{DG}$ & 439 & 0.08 & 4.2 & 0.4 & 87 & 0.66 \\
\hline Speckled worm eel Myrophis punctatus & SW & 415 & 0.08 & 4.3 & 0.5 & 81 & 0.61 \\
\hline Naked goby (large) Gobiosoma bosci & NGL & 367 & 0.07 & 6.1 & 1.2 & 51 & 0.39 \\
\hline Tidewater silverside Menidia beryllina & TS & 318 & 0.06 & 13.4 & 5.2 & 20 & 0.15 \\
\hline Bay anchovy Anchoa mitchilli & $\mathrm{BA}$ & 99 & 0.02 & 4.9 & 1.5 & 17 & 0.13 \\
\hline Skilletfish Gobiesox strumosus & SF & 74 & 0.01 & 3.1 & 0.7 & 20 & 0.15 \\
\hline Clown goby Microgobius gulosus & $\mathrm{CG}$ & 47 & 0.01 & 2.1 & 0.5 & 19 & 0.14 \\
\hline Pinfish Lagodon rhomboides & PF & 44 & 0.01 & 1.7 & 0.3 & 22 & 0.16 \\
\hline Bay whiff Citharichthys spilopterus & BW & 43 & 0.01 & 1.3 & 0.2 & 28 & 0.21 \\
\hline Blackcheek tonguefish Symphurus plagiusa & $\mathrm{BT}$ & 27 & $<0.01$ & 1.5 & 0.2 & 15 & 0.11 \\
\hline Silver perch Bairdiella chrysoura & & 61 & 0.01 & 5.7 & 3.6 & 9 & 0.07 \\
\hline Rainwater killifish Lucania parva & & 33 & $<0.01$ & 6.9 & 3.9 & 4 & 0.03 \\
\hline Spotted seatrout Cynoscion nebulosus & & 14 & $<0.01$ & 2.0 & 0.4 & 6 & 0.04 \\
\hline Chain pipefish Syngnathus louisianae & & 9 & $<0.01$ & 0.8 & 0.0 & 9 & 0.07 \\
\hline Sheepshead minnow Cyprinodon variegatus & & 9 & $<0.01$ & 1.5 & 0.3 & 5 & 0.04 \\
\hline Sheepshead Archosargus probatocephalus & & 5 & $<0.01$ & 1.0 & 0.2 & 4 & 0.03 \\
\hline Gulf killifish Fundulus grandis & & 5 & $<0.01$ & 1.0 & 0.2 & 4 & 0.03 \\
\hline Gulf toadfish Opsanus beta & & 4 & $<0.01$ & 1.0 & 0.2 & 4 & 0.03 \\
\hline Striped mullet Mugil cephalus & & 5 & $<0.01$ & 1.0 & 0.2 & 4 & 0.03 \\
\hline Spot Leiostomus xanthurus & & $S$ & $<0.01$ & 1.0 & 0.2 & 4 & 0.03 \\
\hline Gulf pipefish Syngnathus scovelli & & 4 & $<0.01$ & 1.1 & 0.3 & 3 & 0.02 \\
\hline Red drum Sciaenops ocellatus & & 3 & $<0.01$ & 0.8 & 0.0 & 3 & 0.02 \\
\hline Inshore lizardfish Synodus foetens & & 3 & $<0.01$ & 0.8 & 0.0 & 3 & 0.02 \\
\hline Least puffer Sphoeroides parvus & & 3 & $<0.01$ & 1.3 & 0.4 & 2 & 0.01 \\
\hline Southcrn flounder Paralichthys lethostigma & & 2 & $<0.01$ & 0.8 & 0.0 & 2 & 0.01 \\
\hline Sand seatrout Cynoscion arenarius & & 2 & $<0.01$ & 0.8 & 0.0 & 2 & 0.01 \\
\hline Atlantic needlefish Strongylura marina & & 1 & $<0.01$ & 0.8 & - & 1 & 0.01 \\
\hline Sea catfish Arius felis & & 1 & $<0.01$ & 0.8 & - & 1 & 0.01 \\
\hline Longnose killifish Fundulus similis & & 1 & $<0.01$ & 0.8 & - & 1 & 0.01 \\
\hline
\end{tabular}


Appendix 2. List of 40 species occurring in 147 summer drop samples, ranked by numerical abundance. Twelve species and life history stages (i.e. those with codes) occurred frequently enough $(>0.10)$ to be included in the summer RA ordination. These 12 species and life history stages made up $98 \%$ of the 5980 fishes collected in summer. Densities calculated in no. $\mathrm{m}^{-2}$ for all samples in which that taxon occurred (i.e. excluding samples without any individuals). pl = postlarvae; Num. = total number;

Prop. = proportion; Freq. $=$ frequency of occurrence; $\mathrm{MD}=$ mean density; $\mathrm{SE}=$ standard error of density

\begin{tabular}{|c|c|c|c|c|c|c|c|}
\hline \multirow[t]{2}{*}{ Species } & \multirow[t]{2}{*}{ Code } & \multicolumn{4}{|c|}{ Abundance } & \multicolumn{2}{|c|}{ Occurrence } \\
\hline & & Num. & Prop. & MD & $\mathrm{SE}$ & Freq. & Prop \\
\hline Naked goby (pl) Gobiosoma bosci & NGS & 1946 & 0.33 & 19.5 & 5.9 & 84 & 0.57 \\
\hline Naked goby (large) Gobiosoma bosci & NGL & 1564 & 0.26 & 13.0 & 2.1 & 101 & 0.70 \\
\hline Bay anchovy Anchoa mitchilli & $\mathrm{BA}$ & 664 & 0.11 & 11.6 & 5.0 & 48 & 0.33 \\
\hline Speckled wormeel Myrophis punctatus & SW & 420 & 0.07 & 3.4 & 0.3 & 103 & 0.69 \\
\hline Darter goby Gobionellus boleosoma & $\mathrm{DG}$ & 379 & 0.06 & 4.5 & 0.9 & 71 & 0.48 \\
\hline Tidewater silverside Menidia beryllina & TS & 364 & 0.06 & 9.6 & 2.4 & 32 & 0.22 \\
\hline Silver perch Bairdiella chrysoura & $\mathrm{SP}$ & 147 & 0.03 & 7.7 & 2.6 & 16 & 0.11 \\
\hline Blackcheek tonguefish Symphurus plagiusa & BT & 123 & 0.02 & 1.9 & 0.2 & 55 & 0.37 \\
\hline Clown goby Microgobius gulosus & $\mathrm{CG}$ & 100 & 0.02 & 2.5 & 0.5 & 33 & 0.22 \\
\hline Bay whiff Citharichthys spilopterus & $\mathrm{BW}$ & 65 & 0.01 & 1.6 & 0.2 & 34 & 0.23 \\
\hline Spotted seatrout Cynoscion nebulosus & SS & 43 & 0.01 & 1.4 & 0.2 & 25 & 0.18 \\
\hline Lined sole Achirus lineatus & LS & 28 & $<0.01$ & 1.0 & 0.1 & 23 & 0.16 \\
\hline Gulf toadfish Opsanus beta & & 33 & $<0.01$ & 2.0 & 0.4 & 14 & 0.09 \\
\hline Spotfin mojarra Eucinostomus argenteus & & 17 & $<0.01$ & 2.4 & 1.2 & 6 & 0.04 \\
\hline Least puffer Sphoeroides parvus & & 13 & $<0.01$ & 0.9 & 0.1 & 12 & 0.08 \\
\hline Atlantic spadefish Chaetodipterus faber & & 9 & $<0.01$ & 1.1 & 0.2 & 7 & 0.05 \\
\hline Pinfish Lagodon rhomboides & & 8 & $<0.01$ & 0.8 & 0.0 & 8 & 0.05 \\
\hline Sheepshead Archosargus probatocephalus & & 5 & $<0.01$ & 0.8 & 0.0 & 5 & 0.03 \\
\hline Chain pipefish Syngnathus louisianae & & 5 & $<0.01$ & 0.8 & 0.0 & 5 & 0.03 \\
\hline Sand seatrout Cynoscion arenarius & & 5 & $<0.01$ & 0.8 & 0.0 & 5 & 0.03 \\
\hline Southern flounder Paralichthys lethostigma & & 5 & $<0.01$ & 0.8 & 0.0 & 5 & 0.03 \\
\hline Striped mullet Mugil cephalus & & 3 & $<0.01$ & 0.8 & 0.0 & 3 & 0.02 \\
\hline Gulf menhaden Brevoortia patronus & & 3 & $<0.01$ & 0.8 & 0.0 & 3 & 0.02 \\
\hline Gulf killifish Fundulus grandis & & 3 & $<0.01$ & 1.3 & 0.4 & 2 & 0.01 \\
\hline Freckled blenny Hypsoblennius ionthas & & 3 & $<0.01$ & 1.3 & 0.4 & 2 & 0.01 \\
\hline Atlantic croaker Micropogonias undulatus & & 2 & $<0.01$ & 0.8 & 0.0 & 2 & 0.01 \\
\hline Spot Leiostomus xanthurus & & 2 & $<0.01$ & 0.8 & 0.0 & 2 & 0.01 \\
\hline Skilletfish Gobiesox strumosus & & 2 & $<0.01$ & 1.7 & - & 1 & 0.01 \\
\hline Striped anchovy Anchoa hepsetus & & 2 & $<0.01$ & 1.7 & - & 1 & 0.01 \\
\hline Gulf pipefish Syngnathus scovelli & & 2 & $<0.01$ & 0.8 & 0.0 & 2 & 0.01 \\
\hline Red drum Sciaenops ocellatus & & 2 & $<0.01$ & 0.8 & 0.0 & 2 & 0.01 \\
\hline Sea catfish Arius felis & & 2 & $<0.01$ & 0.8 & 0.0 & 2 & 0.01 \\
\hline Gulf kingfish Menticirrhus littoralis & & 2 & $<0.01$ & 0.8 & 0.0 & 2 & 0.01 \\
\hline Gold brotula Gunterichthys longipenis & & 2 & $<0.01$ & 1.7 & - & 1 & 0.01 \\
\hline Mojarra Eucinostomus spp & & 1 & $<0.01$ & 0.8 & - & 1 & 0.01 \\
\hline Rainwater killifish Lucania parva & & 1 & $<0.01$ & 0.8 & - & 1 & 0.01 \\
\hline Striped blenny Chasmodes bosquianus & & 1 & $<0.01$ & 0.8 & - & 1 & 0.01 \\
\hline Atlantic needlefish Strongylura marina & & 1 & $<0.01$ & 0.8 & - & 1 & 0.01 \\
\hline Crevalle jack Caranx hippos & & 1 & $<0.01$ & 0.8 & - & 1 & 0.01 \\
\hline Ladyfish Elops saurus & & 1 & $<0.01$ & 0.8 & - & 1 & 0.01 \\
\hline Gray snapper Lutjanus griseus & & 1 & $<0.01$ & 0.8 & - & 1 & 0.01 \\
\hline
\end{tabular}

\section{IITERATURE CITED}

Baumann, R. H. (1987). Physical variables. In: Conner, W. H., Day, J. W. Jr (eds.) The ecology of Barataria Basin, Louisiana: an estuarine profile, Chap. 2. U.S. Fish Wildl. Serv. biol. Rep. 85 (7.13): 8-17

Blaber, S. J. M., Blaber, T G. (1980). Factors affecting the distribution of juvenile estuarine and inshore fish. J. Fish Biol. 17: 143-162

Boesch, D. F. (1977). A new look at the zonation of benthos along the estuarine gradient. In: Coull, B. C. (ed.) Ecology of marine benthos. University of South Carolina Press, Columbia, p. 245-266

Boesch, D. F., Turner, R. E. (1984). Dependence of fishery species on salt marshes: the role of food and refuge. Estuaries 7: 460-468

Childers, D. L., Day, J. W., Muller, R. A. (1990). Relating climatological forcing to coastal water levels in Louisiana estuaries and the potential importance of El NiñoSouthern Oscillation events. Clim. Res. 1: 31-42

Connell, J. H. (1980). Diversity and the coevolution of competitors, or the ghost of competition past. Oikos 35: 131-138

Conner, W. H., Day, J. W. Jr (1987). Description of the basin. In: Conner, W. H., Day, J. W. Jr (eds.) The ecology of Barataria Basin, Louisiana: an estuarine profile, Chap. 1 U.S. Fish Wildl. Serv. biol. Rep. 85 (7.13): 1-7

Deegan, L. A., Thompson B. A. (1985). The ecology of fish communities in the Mississippi River deltaic plain. In: 
Yáñez-Arancibia, A. (ed.) Fish community ecology in estuaries and coastal lagoons: towards an ecosystem integration. DR (R) Universidad Nacional Autónoma de Mexico, Universitaria, Mexico City, p. 35-56

Felley, J. D. (1987). Nekton assemblages of three tributaries to the Calcasieu estuary, Louisiana. Estuaries 10: 321-328

Gauch, H. G. (1982). Multivariate analysis in community ecology. Cambridge University Press, New York

Gleason, D. F. (1986). Utilization of salt marsh plants by postlarval brown shrimp: carbon assimilation rates and food preferences. Mar. Ecol. Prog. Ser. 31: 151-158

Gleason, D. F., Wellington, G. M. (1988). Food resources of postlarval brown shrimp (Penaeus aztecus) in a Texas salt marsh. Mar. Biol. 97: 329-337

Hastings, R. E., Turner, D. A., Thomas, R. G. (1987). The fish fuana of Lake Maurepas, an oligohaline part of the Lake Pontchartrain estuary. NE Gulf Sci. 9: 89-98

Hettler, W. F. Jr (1989). Nekton use of regularly-flooded saltmarsh cordgrass habitat in North Carolina, USA. Mar. Ecol. Prog. Ser. 56: 111-118

Hill, M. O. (1973). Reciprocal averaging: an eigenvector method of ordination. J. Ecol. 61: 237-249

Hoese, H. K., Moore, R. H. (1977). Fishes of the Gulf of Mexico, Texas, Louisiana and adjacent waters. Texas A \& $M$ Univ. Press, College Station and London

Keup, L., Bayless, J. (1964). Fish distribution at varying salinities in Neuse River basin, North Carolina. Chesapeake Sci. 5: 271-280

Kneib, R. T. (1984). Patterns of invertebrate distribution and abundance in the intertidal salt marsh: causes and questions. Estuaries 7: 392-412

Lippson, A. J., Moran, R. L. (eds.) (1974). Manual for identification of early developmental stages of fishes of the Potomac River estuary. MD DNR PPSP-MP-13. Martin Marietta, Baltimore

Livingston, R. J. (1976). Diurnal and seasonal fluctuations of organisms in a north Florida estuary. Estuar. coast. mar Sci. 4: $373-400$

Livingston, R. J. (1988). Inadequacy of species-level designations for ecological studies of coastal migratory fishes Environ. Biol. Fish. 22: 225-234

Moser, M. A., Gerry, L. R. (1989). Differential effects of salinity changes on two estuarine fishes, Leiostomus xanthurus and Micropogonias undulatus. Estuaries 12: 35-41

Moyle, P. B., Cech, J. J. Jr (1988). Fishes: an introduction to ichthyology. Prentice-Hall, Englewood Cliffs

Moyle, P. B., Daniels, R. A., Herbold, B., Baltz, D. M. (1986) Patterns in distribution and abundance of a noncoevolved assemblage of estuarine fishes in Califormia. Fish. Bull. U.S. 84: 105-117

Peterson, M. S., Ross, S. T (1991). Dynamics of littoral fishes and decapods along a coastal river-estuarine gradient Estuar. coast. Shelf Sci. 33: 467-483

Pielou, E. C. $\{1984\}$. The interpretation of ecological data John Wiley \& Sons, New York

Pimentel, R. A., Smith, J. D. (1986). BIOETAT II. A multivariate statistical toolbox. Sigma Soft, Placentia, CA

Quinn, N. J. (1980). Analysis of temporal changes in fish assemblages in Serpentine Creek, Queensland. Environ. Biol. Fish. 5: 117-133

Raffaelli, D., Karakassis, I., Galloway, A. (1991). Zonation schemes on sandy shores: a multivariate approach. J. exp. mar. Biol. Ecol. 148: 241-253

Rogers, S. G., Targett, T E., van Sant, S. B. (1984). Fishnursery use in Georgia salt-marsh estuaries: the influence of springtime freshwater conditions. Trans. Am. Fish. Soc 113: 595-606
Ross, S. T., McMichael, R. H. Jr, Ruple, D. L. (1987) Seasonal and diel variation in the standing crop of fishes and macroinvertebrates from a Gulf of Mexico surf zone. Estuar. coast. Shelf Sci. 25: 391-412

Ross, S. W. Epperly, S. P. (1985). Utilization of shallow estuarine nursery areas by fishes in Pamlico Sound and adjacent tributaries North Carolina. In: Yánez-Arancibia, A. (ed.) Fish community ecology in estuaries and coastal lagoons: towards an ecosystem integration. DR (R) Universidad Nacional Autónoma de Mexico, Universitaria, Mexico City, p. 207-232

Rounsefell, G. A. (1964). Preconstruction study of the fisheries of the estuarine areas traversed by the Mississippi RiverGulf outlet project. Fish. Bull. U.S. 63: 373-393

Rozas, L. P., Mclvor, C. C., Odum, W. E. (1988). Intertidal rivulets and creek banks: corridors between tidal creeks and marshes. Mar. Ecol. Prog. Ser. 47: 303-307

Sasser, C. E. (1977). Distribution of vegetation in Louisiana coastal marshes in response to tidal flooding. Master's thesis. Louisiana State University, Baton Rouge

Shenker, J. M., Dean, J. M. (1979). The utilization of an intertidal salt marsh creek by larval and juvenile fishes: abundance, diversity and temporal variation. Estuaries 2: 154-163

Sissenwine, M. P. (1984). Why fish populations vary? In: May, R. M. (ed.) Exploitation of marine communities. Dahlem Konferenze 1984. Springer-Verlag, New York

Subrahmanyam, C. B., Coultas, C. L. (1980). Studies on the animal communities in two north Florida salt marshes. Part III. Seasonal fluctuations of fish and macroinvertebrates. Bull. mar. Sci. 30: 790-818

Subrahmanyam, C. B., Drake, S. H. (1975). Studies on the animal communities in two north Florida salt marshes. Part I. Fish communities. Bull. mar. Sci. 25: 445-465

Thompson, B. A., Forman, W. (1987). Nekton. In: Conner, W. H., Day, J. W. Jr (eds.) The ecology of Barataria Basin: an estuarine profile, Chapt. 7. U.S. Fish Wildl. Serv. biol. Rep. 85 (7.13): $80-95$

Thorman, S. (1982). Niche dynamics and resource partitioning in a fish guild inhabiting a shallow estuary on the Swedish west coast. Oikos 39: 32-39

Van Dolah, R. F. (1978). Factors regulating the distribution and population dynamics of the amphipod Gammarus palustris in an intertidal salt marsh. Ecol. Monogr. 48: 191-217

Wartenberg, D., Ferson, S., Roglf, F. J. (1987). Putting things in order: a critique of detrended correspondence analysis. Am. Nat. 129: 434-448

Weinstein, M. P., Brooks, H. A. (1983). Comparative ecology of nekton residing in a tidal creek and adjacent seagrass meadow: community composition and structure. Mar. Ecol. Prog. Ser. 12: 15-27

Weinstein, M. P., Weiss, S. L., Walters, M. F. (1980). Multiple determinants of community structure in shallow marsh habitats, Cape Fear River estuary, North Carolina. Mar. Biol. 58: 227-243

Werner, E. E., Gilliam, J. F., Hall, D. J., Mittelbach, G. G. (1983). An experimental test of the effects of predation risk on habitat use in fish. Ecology 64: 1540-1548

Whittaker, R. H. (1967). Gradient analysis of vegetation. Biol. Rev. 42: 207-264

Zar, J. H. (1984). Biostatistical analysis, 2nd edn. Prentice Hall. Inc., Englewood Cliffs

Zilberberg, M. H. (1966). Seasonal occurrence of fishes in a coastal marsh of northwest Florida. Publ. Inst. mar. Sci. Univ. Tex. 11 126-134

Zimmerman, R., Minello, T (1984). Densities of Penaeus aztecus, Penaeus setiferus, and other natant macrofauna in a Texas salt marsh. Estuaries 7: 421-433 